\title{
ILLUSTRATIONS
}

Figure $0.1 \quad$ Color chart by Natalie Kalmus (1932). 12

Figure 0.2 Film stars illustrating Kalmus's color chart (1932). 13

Figure 1.1 Color sphere from Atlas of the Munsell Color System (1915). 28

Figure 1.2 A Color Notation (1919). 29

Figure 1.3 The German submarine Deutschland being unloaded of aniline cargo (1916). 31

Figure 1.4 The Kodak Research Laboratories (1921). 39

Figure 1.5 Kenneth Mees's outline of the areas of photographic inquiry (1917). 41

Figure 1.6 Kodak's Abridged Scientific Publications, beginning in 1913. 43

Figure 1.7 Kodak's Monthly Abstract Bulletins, beginning in 1916. 44

Figure 1.8 Loyd Jones and Lewis Townsend's experiments with projecting color music (1925). 46

Figure 1.9 Eastman-Kodak emulsions (1908). 49

Figure 1.10 Tinting formulas by Kodak (1924). 50

Figure 1.11 Sketches for a rapid tinting machine (1923). 51

Figure 1.12 Overview of Technicolor's lab and staff (1924). 54

Figure 1.13 Leonard Troland's Technicolor notebook covering patent research. 59

Figure 1.14 Section 8 on "Coloring" patents from Troland's Technicolor Notebooks. 60

Figure 1.15 Screenland feature on Taming of the Shrew (1929). 62

Figure 2.1 The Octopus Gown (Photoplay Magazine 1921). 90 
xii Illustrations

Figure 3.1 The ciné-dance-hall of the Café Aubette in Strasbourg (1928). 107

Figure 3.2 Warners' Theatre on Broadway advertising Don Juan (ca. 1926). 109

Figure 3.3 Exterior of the Atrium Theatre in Berlin (1929). 110

Figure 3.4 Loïe Fuller skirt dances (1896). 116

Figure 3.5 Thomas Wilfred performing his Clavilux color organ (1924). 117

Figure 3.6 Thomas Wilfred installation of the Clavilux color organ in in the Bal Tabarin Room, Chicago (1930). 120

Figure 3.7 Mary Hallock Greenewalt demonstrating the Sarabet color organ. 121

Figure 3.8 Zdeněk Pešánek’s “Spectrophone” (ca. 1926). 124

Figure 3.9 Holophane lighting in cinemas (1929). 133

Figure 3.10 Holophane lighting at the Ritz Cinema, Birmingham (1929). 135

Figure 4.1 Bruno Taut's Glashaus at the Cologne Deutscher Werkbund Exhibition (1914). 148

Figure 4.2 The mural workshop at the Bauhaus, Dessau (1926). 152

Figure 4.3 Walter Gropius's diagram of the curriculum at the Bauhaus (1923). 155

Figure 4.4 Johannes Itten in front of his Color Sphere (1921). 157

Figure 4.5 The score for Ludwig Hirschfield-Mack's version of Farben Licht-Spiele. 160

Figure 4.6 Kurt Schwerdtfeger's Reflektorische Farblichtspiele. 164

Figure 4.7 The program of Der Absolute Film screening, UFA Palast, Berlin (1925). 166

Figure 4.8 Lotte Reiniger's sponsored film Die Barcarole (1924). 167

Figure 4.9 Nosferatu (1922). 171

Figure 4.10 Walter Ruttmann's "Dream of the Hawks" in Die Nibelungen: Siegfried (1924). 177

Figure 4.11 Opus 1 (1921). 178

Figure 4.12 Further matching motifs Der Sieger: Ein Film in Farben (1922). 179

Figure 4.13 Dada periodical 391, no. 7 (Francis Picabia, 1917). 184

Figure 4.14 Marcel L'Herbier's exhibit at the Exposition internationale des arts décoratifs et industriels modernes in Paris (1925). 191

Figure 4.15 Original frame slugs with color information for L'Inhumaine (1924). 193

Figure 4.16 Cottage on Dartmoor (1929). 196

Figure 5.1 A composite tryptic image in Napoléon (1927). 218

Figure 6.1 The Technicolor Camera Department (1930). 229

Figure 6.2 The Multicolor attachment on a Mitchell camera (1930). 231

Figure 6.3 James Wong Howe and Max DuPont (1929). 232

Figure 6.4 Max Du Pont and Mary Mabery (1929). 235

Figure 6.5 Advertisement for Vitaphone's Technicolor Musical Review (1930). 240

Figure 6.6 Redskin (1929). 243

Figure 6.7 Advertisement by Gustav Brock (1935). 252

Figure 6.8 Advertisement by Gustav Brock for his work on The Vampire Bat (1933). 254 
Figure 6.9 The Pathéchrome dye-applicator device (1931). 257

Figure 6.10 Kodak Sonochrome advertisement (1930). 263

Figure 6.11 Dracula (Tod Browning). 266

Figure 6.12 Frame slug from Dracula (1931). 268

\section{Color Plates}

Color Plate o.1 Napoléon (1927).

Color Plate 1.1 Color guidebook (1910).

Color Plate 1.2 Eastman Kodak's tinting guidebook (1927).

Color Plate 1.3 Pathé Frères' tinting guidebook (ca. 1925).

Color Plate 2.1 Le home moderne (1929).

Color Plate 2.2 Office design by Etienne Kohlmann (1930).

Color Plate 2.3 Lupe Vélez's bedroom colors (1929).

Color Plate 2.4 The hand-colored title of Changing Hues (1922).

Color Plate 2.5 Stenciling in Changing Hues (1922).

Color Plate 2.6 The final hand-colored and stenciled shots in Changing Hues (1922).

Color Plate 2.7 Raquel Torres in Technicolor's Fashion News.

Color Plate 2.8 Der karierte Regenmantel (The Checkered Raincoat, 1917).

Color Plate 2.9 A Handschiegled pink cigarette in The Affairs of Anatol (1921).

Color Plate 2.10 An Art Deco-styled room tinted rose in Gribiche (1926).

Color Plate 2.11 Lotus Flower in green framed against the red flowers of her garden, in The Toll of the Sea (Chester M. Franklin, U.S. 1922).

Color Plate 2.12 Lotus Flower and Little Allen, now washed clean of his Eastern colors, in The Toll of the Sea (Chester M. Franklin, U.S., 1922).

Color Plate 2.13 Eve's dress in the fashion show of Fig Leaves (Howard Hawks, U.S., 1926). Courtesy of Karl Thiede.

Color Plate 3.1 The ciné-dance-hall of the Café Aubette in Strasbourg (1928; restored 2006).

Color Plate 3.2 [Kaleidoscope] (1925).

Color Plate 3.3 Thomas Wilfred's Clavilux Junior (1930).

Color Plate 3.4 Thomas Wilfred's sketch for mounting the Clavilux on top of skyscrapers (1929).

Color Plate 3.5 Mary Hallock Greenewalt's "first mapping” of a color score (ca. 1906).

Color Plate 3.6 Opus 1 (1921).

Color Plate 3.7 Raumlichtkunst (1926/2012), reconstruction by Center for Visual Music.

Color Plate 3.8 The Theater Tuschinski in Amsterdam (1921).

Color Plate 4.1 Herbert Bayer's design for a cinema, "Kinogestaltung" (1924-1925). 
Color Plate 4.2 Reflektorische Farblichtspiele (Reflecting Colour-Light-Play, 1922; 2016).

Color Plate 4.3 Opus III (1924).

Color Plate 4.4 Carl Otto Czeschka’s illustrations of Die Nibelungen (1909).

Color Plate 4.5 Die Nibelungen: Siegfried (1924).

Color Plate 4.6 Tinted and toned colors, and positive cutting in The Cabinet of Dr. Caligari (1920).

Color Plate 4.7 Hand tinting in Ballet mécanique (1924).

Color Plate 4.8 L'inhumaine (1923).

Color Plate 4.9 Handschiegl in Salomé (1923).

Color Plate 4.10 The execution of Jokaanan in Salomé (1923).

Color Plate 4.11 Tinting and toning in Danse Macabre (1922).

Color Plate 5.1 Amber tinting in Smouldering Fires (1925).

Color Plate 5.2 Violet tinting in Smouldering Fires (1925).

Color Plate 5.3 Tinting and Handschiegl effects in The Fire Brigade (1926).

Color Plate 5.4 Tinting and Handschiegl in Wings (1927).

Color Plate 5.5 Technicolor in The Phantom of the Opera (1925).

Color Plate 5.6 Handschiegl in The Phantom of the Opera (1925).

Color Plate 5.7 The Glorious Adventure (1922).

Color Plate 5.8 Das Weib des Pharao (The Loves of Pharaoh, 1921).

Color Plate 5.9 The Lodger (1926).

Color Plate 5.10 Stenciling in Cirano di Bergerac (1923/1925).

Color Plate 5.11 Stenciling in Michel Strogoff (1926).

Color Plate 5.12 Stenciling in Casanova (1927).

Color Plate 5.13 Blue toning and pink tinting in Napoléon (1927).

Color Plate 5.14 Blue toning in Napoléon (1927).

Color Plate 5.15 Amber tinting in Napoléon (1927).

Color Plate 5.16 Lonesome (1928).

Color Plate 5.17 Fringing in The Open Road (1925).

Color Plate 5.18 Cosmopolitan London (1924).

Color Plate 6.1 Redskin (1929).

Color Plate 6.2 King of Jazz (1930).

Color Plate 6.3 King of Jazz (1930).

Color Plate 6.4 The film bursting into flames in The Death Kiss (1932).

Color Plate 6.5 A stencil-sound film from the Kodak Film Samples Collection. 